Results of 2001 Groundwater Sampling in Support of Conditional No Longer Contained-In Determination for the Snake River Plain Aquifer in the Vicinity of the Idaho Nuclear Technology and Engineering Center

T. R. Meachum

April 2002

Idaho National Engineering and Environmental Laboratory Bechtel BWXT Idaho, LLC 


\section{Results of 2001 Groundwater Sampling in Support of Conditional No Longer Contained-In Determination for the Snake River Plain Aquifer in the Vicinity of the Idaho Nuclear Technology and Engineering Center}

T. R. Meachum

April 2002

Idaho National Engineering and Environmental Laboratory Idaho Falls, Idaho 83415

Prepared for the

U.S. Department of Energy

Assistant Secretary for Environmental Management

Under DOE Idaho Operations Office

Contract DE-AC07-99ID13727 


\begin{abstract}
This report summarizes the results of sampling five groundwater monitoring wells in the vicinity of the Idaho Nuclear Technology and Engineering Center at the Idaho National Engineering and Environmental Laboratory in 2001. Information on general sampling practices, quality assurance practices, parameter concentrations, representativeness of sampling results, and cumulative cancer risk are presented. The information is provided to support a conditional No Longer Contained-In Determination for the Snake River Plain Aquifer in the vicinity of the Idaho Nuclear Technology and Engineering Center.
\end{abstract}




\section{SUMMARY}

This report summarizes the results of sampling five groundwater monitoring wells in the vicinity of the Idaho Nuclear Technology and Engineering Center (INTEC) at the Idaho National Engineering and Environmental Laboratory (INEEL) during 2001. The information is provided to support a conditional No Longer Contained-In (NLCI) determination for the Snake River Plain Aquifer in the vicinity of INTEC.

This report contains the following information:

- Background information

- General sampling and quality assurance practices

- April and October 2001 sampling results

- Discussion of sampling anomalies

- Comparison of results to Preliminary Remediation Goals

- Discussion of cumulative cancer risk

- Representativeness of 2001 purge water

- Continued annual monitoring and associated trends.

The five wells in the vicinity of INTEC selected as indicator wells are USGS-038, USGS-044, USGS-047, USGS-114, and USGS-121. These wells were sampled for metals, volatile organics, and semi-volatile organics in April and October 2001, with the October 2001 sample event representing the Idaho Department of Environmental Quality (DEQ)-required annual sample event. Results from both sampling events in 2001 are summarized and the risk, as determined per the Environmental Protection Agency (EPA) Region IX Preliminary Remediation Goals (PRG) calculations, is presented.

Based on the results of the October sampling of the five indicator wells, the cumulative cancer risk associated with organic constituents is below the $1 \mathrm{E}-05$ cumulative risk required by the DEQ for the NLCI determination.

For metal constituents, cumulative risk is determined solely from arsenic, since arsenic is the only metal with the PRG based on a cancer risk. During the October sampling, arsenic was detected in two of the indicator wells (i.e., USGS-038 and USGS-047) at concentrations in excess of those associated with a $1 \mathrm{E}-05$ risk. Arsenic was not detected in any of the five indicator wells during the April 2001 sampling. While the concentrations of arsenic detected in the two indicator wells exceeded the concentrations associated with a 1E-05 risk, the concentrations are within levels historically detected in the Snake River Plain Aquifer (SRPA) and do not necessarily indicate an impact from INTEC operations. In addition, the concentrations of arsenic detected in USGS-038 and 
USGS-047 in October 2001 were both below the recently adopted drinking water standard of $10 \mu \mathrm{g} / \mathrm{L}$.

Results of the October annual sampling show that the five indicator wells are representative of other aquifer wells in the vicinity of INTEC and were sampled at depths representative of the saturated zone in the vicinity of INTEC.

The five indicator wells will continue to be sampled on an annual basis with the results reported to the DEQ. As annual sampling continues and sufficient results become available, constituent trends will be assessed and reported to the DEQ. 


\section{CONTENTS}

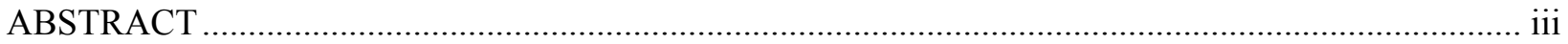

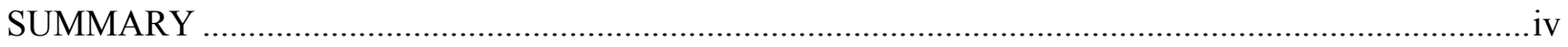

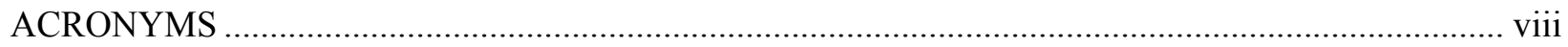

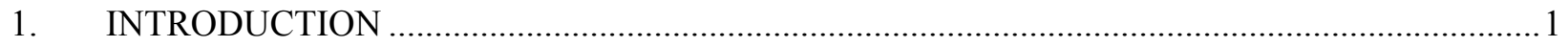

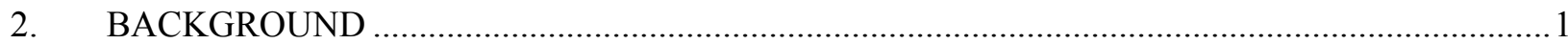

2.1 Idaho National Engineering and Environmental Laboratory Site Description....................... 1

2.2 Idaho Nuclear Technology and Engineering Center Site Description....................................

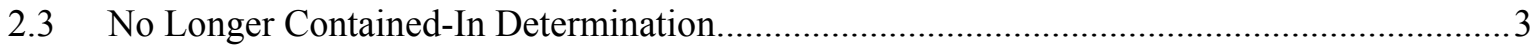

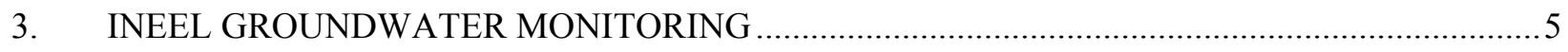

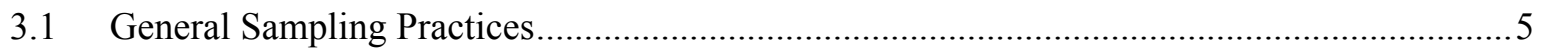

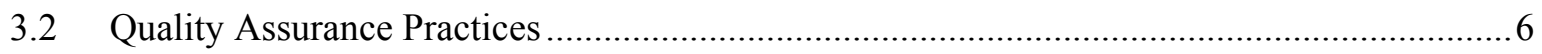

3.2.1 Field Quality Control Samples...........................................................................

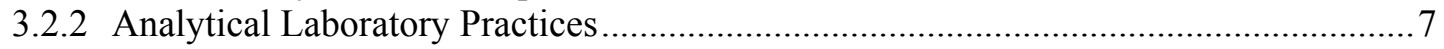

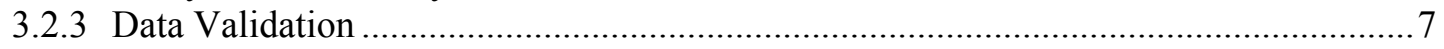

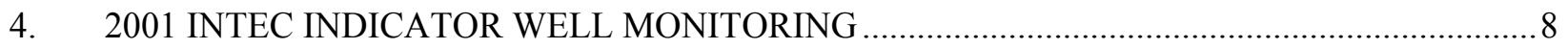

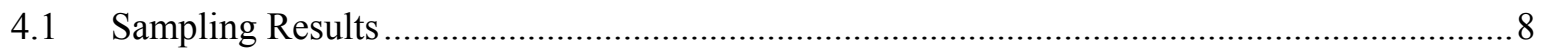

4.1.1 Volatile and Semi-Volatile Organic Constituents ..................................................

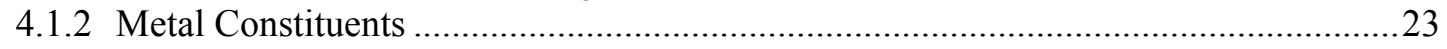

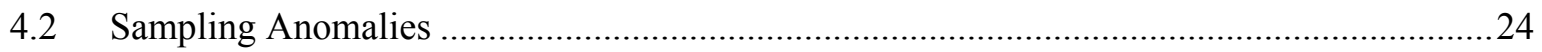

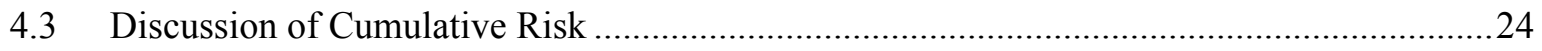

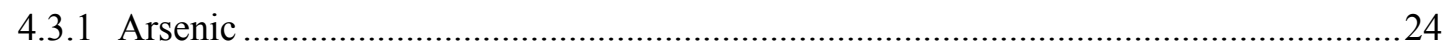

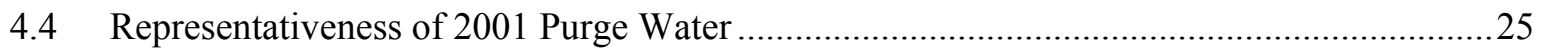

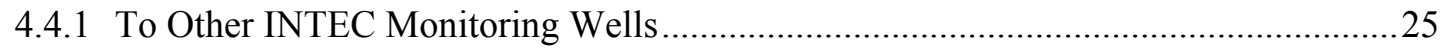

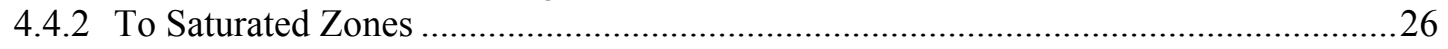

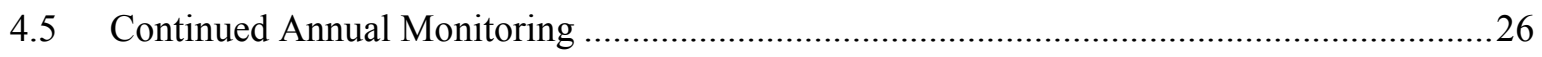

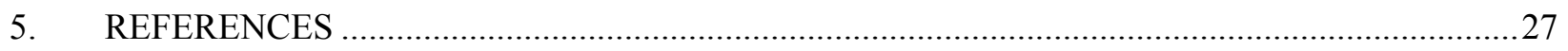


Appendix A-Environmental Monitoring Technical Procedures

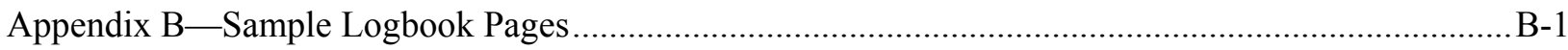

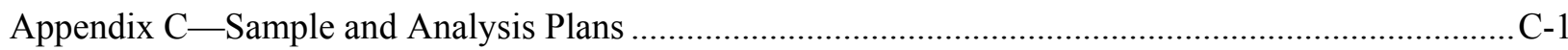

\section{FIGURES}

1. Idaho National Engineering and Environmental Laboratory …..................................................2

2. Locations of Idaho Nuclear Technology and Engineering Center monitoring wells...........................4

\section{TABLES}

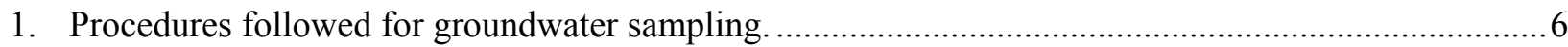

2. Summary of October 2001 detected volatile and semi-volatile organic results..................................

3. Summary of April 2001 detected volatile and semi-volatile organic results...................................... 14

4. Tentatively identified compounds from October 2001 organic analysis. .........................................19

5. Tentatively identified compounds from April 2001 organic analysis.............................................20

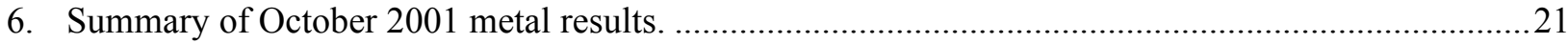

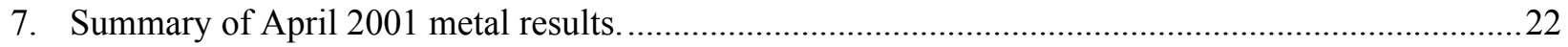

8. Constituent concentration ranges from indicator wells and other INTEC wells sampled

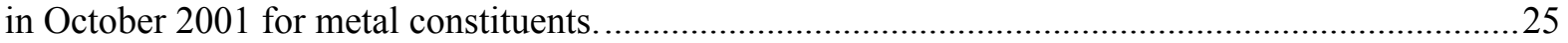

9. 2001 well depths and prepurge water levels for five INTEC indicator wells.................................26 


\section{ACRONYMS}

\begin{tabular}{|c|c|}
\hline CA & cancer risk \\
\hline DEQ & Department of Environmental Quality \\
\hline EPA & Environmental Protection Agency \\
\hline ESRP & Eastern Snake River Plain \\
\hline GC/MS & gas chromatography/mass spectrometry \\
\hline GDE & guide document \\
\hline GMP & Groundwater Monitoring Program \\
\hline IDL & instrument detection limit \\
\hline INEEL & Idaho National Engineering and Environmental Laboratory \\
\hline INTEC & Idaho Nuclear Technology and Engineering Center \\
\hline $\mathrm{L} \& \mathrm{~V}$ & Limitations and Validation \\
\hline $\mathrm{MCP}$ & management control procedure \\
\hline MDL & method detection limit \\
\hline NLCI & no longer-contained-in \\
\hline PRG & Preliminary Remediation Goal \\
\hline QC & quality control \\
\hline RCRA & Resource Conservation and Recovery Act \\
\hline SAP & Sampling and Analysis Plan \\
\hline SOW & Statement of Work \\
\hline SRPA & Snake River Plain Aquifer \\
\hline TIC & tentatively identified compound \\
\hline TOS & Task Order Statement of Work \\
\hline TPR & technical procedure \\
\hline USGS & United States Geological Survey \\
\hline WLAP & Wastewater Land Application Permit \\
\hline
\end{tabular}




\section{Results of 2001 Groundwater Sampling in Support of Conditional No Longer Contained-In Determination for the Snake River Plain Aquifer in the Vicinity of the Idaho Nuclear Technology and Engineering Center}

\section{INTRODUCTION}

This report presents the results of sampling five groundwater monitoring wells in the vicinity of the Idaho Nuclear Technology and Engineering Center (INTEC) at the Idaho National Engineering and Environmental Laboratory (INEEL) during 2001. The information is being submitted at the request of the Idaho Department of Environmental Quality (DEQ) (Monson 2001a) and is provided to support a conditional No Longer Contained-In (NLCI) determination for the Snake River Plain Aquifer (SRPA) in the vicinity of INTEC.

The Environmental Protection Agency's (EPA) Resource Conservation and Recovery Act (RCRA) "contained-in policy," as adopted by the DEQ, provides for an authorized state to approve a No Longer Contained-In request when environmental media and/or debris that come in contact with listed waste exhibit hazardous constituents below health based levels (INEEL 2000). A request for a NLCI determination was initially made to the DEQ in February 2000 (Guymon 2000). In August 2000, the DEQ agreed that five indicator wells located at INTEC could be used for the purpose of determining risk (per Region IX Preliminary Remediation Goals calculations) associated with volatile organics, semi-volatile organics, and metals present in purge waters collected in the vicinity of INTEC (Monson 2000). This report documents the results of the 2001 sampling of these five indicator wells for the DEQ-specified constituents.

\section{BACKGROUND}

\subsection{Idaho National Engineering and Environmental Laboratory Site Description}

The INEEL is approximately $890 \mathrm{mi}^{2}$ and is located on the Eastern Snake River Plain (ESRP) in southeastern Idaho (Figure 1). It was established as a nuclear energy research and development testing station in the late 1940s and was designated a National Environmental Research Park in 1975.

The primary groundwater source of the region is the Snake River Plain Aquifer (SRPA). The SRPA is approximately $199 \mathrm{mi}$ long and 20 to $60 \mathrm{mi}$ wide and encompasses an area of about 9,650 $\mathrm{mi}^{2}$. The depth to the SRPA varies from $200 \mathrm{ft}$ in the northeastern corner of the INEEL to $886 \mathrm{ft}$ in the southeastern corner. The SRPA is approximately $250 \mathrm{ft}$ thick (Robertson 1974). The SRPA is the Eastern Snake River Plain's source of groundwater. It is also the source of process water and drinking water for both on and off the INEEL. The SRPA may contain as much as $2 \times 10^{9}$ acre-ft of water. Approximately $6.5 \times 10^{6}$ acre- $\mathrm{ft}$ of water is used for irrigation upgradient of the Hagerman area. Aquifer recharge occurs from infiltration of irrigation water $\left(1.5 \times 10^{6}\right.$ acre-ft), river seepage $\left(1.3 \times 10^{6}\right.$ acre- $\left.\mathrm{ft}\right)$, and infiltration of precipitation $\left(0.6 \times 10^{6}\right.$ acre-ft) (Lewis and Jensen 1984). Groundwater in the SRPA flows generally to 


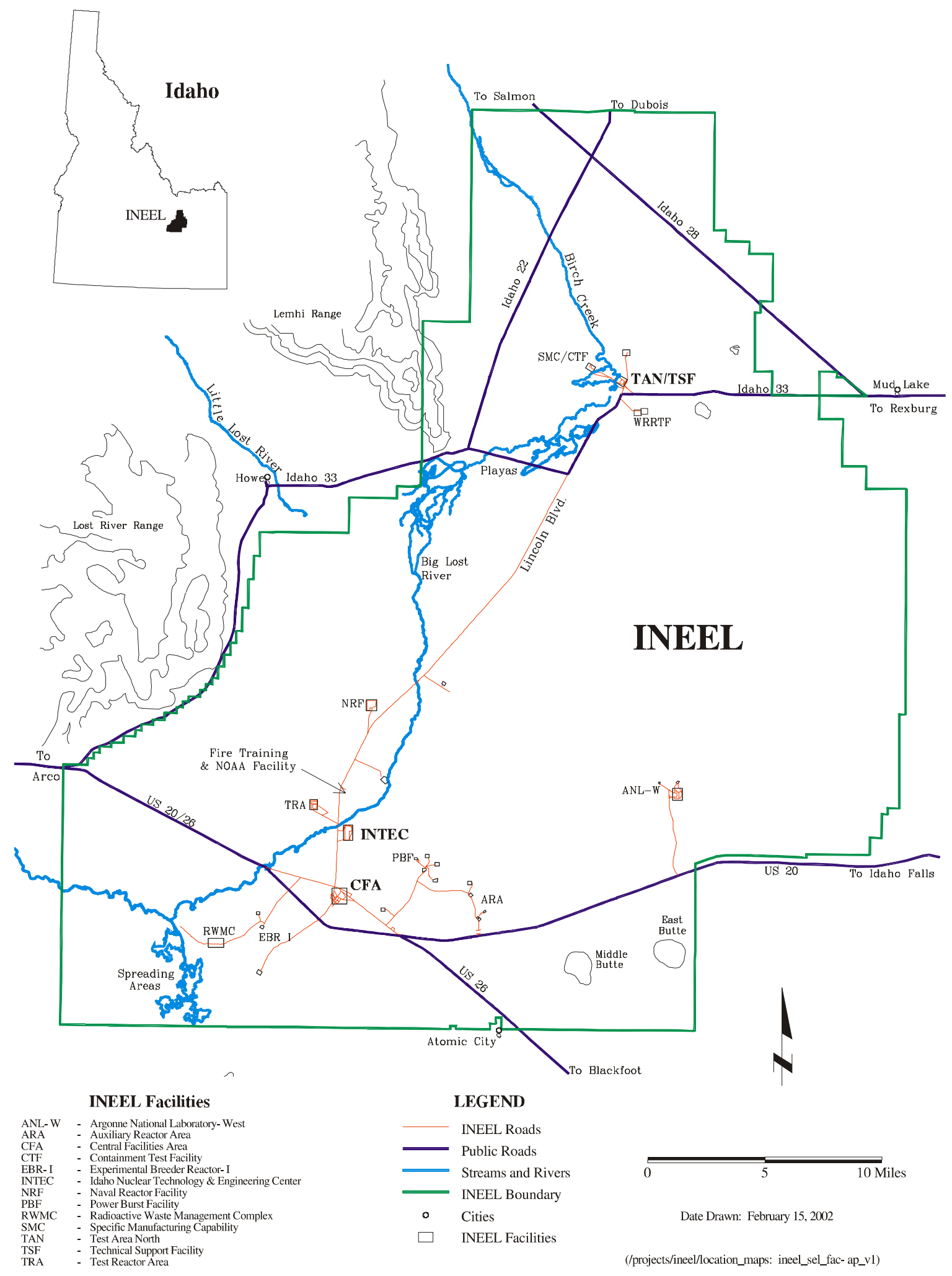

Figure 1. Idaho National Engineering and Environmental Laboratory. 
the southwest, although locally the direction of flow is influenced by recharge from rivers, surface water spreading areas, and heterogeneities in the aquifer.

\subsection{Idaho Nuclear Technology and Engineering Center Site Description}

The Idaho Nuclear Technology and Engineering Center (INTEC) is a 210-acre, multipurpose plant located on the INEEL (refer to Figure 1). It was constructed in 1951 and presently includes approximately 230 buildings and structures. Within INTEC are all of the facilities necessary to receive and store spent nuclear fuels, process the fuels to recover uranium-235, and handle waste generated by those functions. However, due to a change in mission in 1992, uranium-235 is no longer recovered at INTEC. Currently, INTEC receives and stores spent nuclear fuel and isolates and solidifies the waste fission products resulting from the spent fuel recovery process. In addition, research and development work is conducted to develop and improve fuel management and waste processing technologies.

From 1953 until 1984, an injection well was used at the INTEC to dispose of radioactive liquid waste generated during fuel reprocessing. In 1982 and 1984, two percolation ponds were constructed at INTEC to replace the injection wells. Past operations at the INTEC resulted in low levels of listed hazardous waste being discharged to the percolation ponds via the service waste system (INEEL 2000). Currently, the existing two percolation ponds receive only the discharge of nonhazardous wastewater. Hazardous wastewater from INTEC processes and laboratories is disposed of in accordance with applicable Resource Conservation and Recovery Act regulations.

Under the Comprehensive Environmental Response, Compensation, and Liability Act Record of Decision for Operable Unit 3-13 (DOE-ID 1999), it was decided to discontinue discharging to the two existing percolation ponds. In January 2000, a Wastewater Land Application Permit application was submitted to DEQ to construct and operate two new percolation ponds (Graham 2000a). The DEQ approved plans and specifications to construct the new ponds in May 2000 (Hall 2000), and the new ponds are currently under construction. The existing two percolation ponds will remain in use until the new percolation ponds become operational.

\subsection{No Longer Contained-In Determination}

The Environmental Protection Agency's (EPA) Resource Conservation and Recovery Act (RCRA) "contained-in policy," as adopted by the DEQ, provides for an authorized state to approve a No Longer Contained-In request (NLCI) when environmental media and/or debris that come in contact with listed waste exhibits hazardous constituents below health based levels (INEEL 2000). A request for a NLCI determination for purge water from wells in the vicinity of INTEC was initially made to the DEQ in February 2000 (Guymon 2000). In August 2000, the DEQ agreed that five indicator wells located at INTEC could be used for the purpose of determining risk (per Region IX Preliminary Remediation Goals calculations) associated with volatile organics, semi-volatile organics, and metals present in purge waters collected in the vicinity of INTEC (Monson 2000).

Figure 2 shows the monitoring wells in the vicinity of INTEC. The five wells selected as indicator wells for the NLCI determination are shown in green and are as follows:

\footnotetext{
- $\quad$ USGS-038

- $\quad$ USGS-044
} 


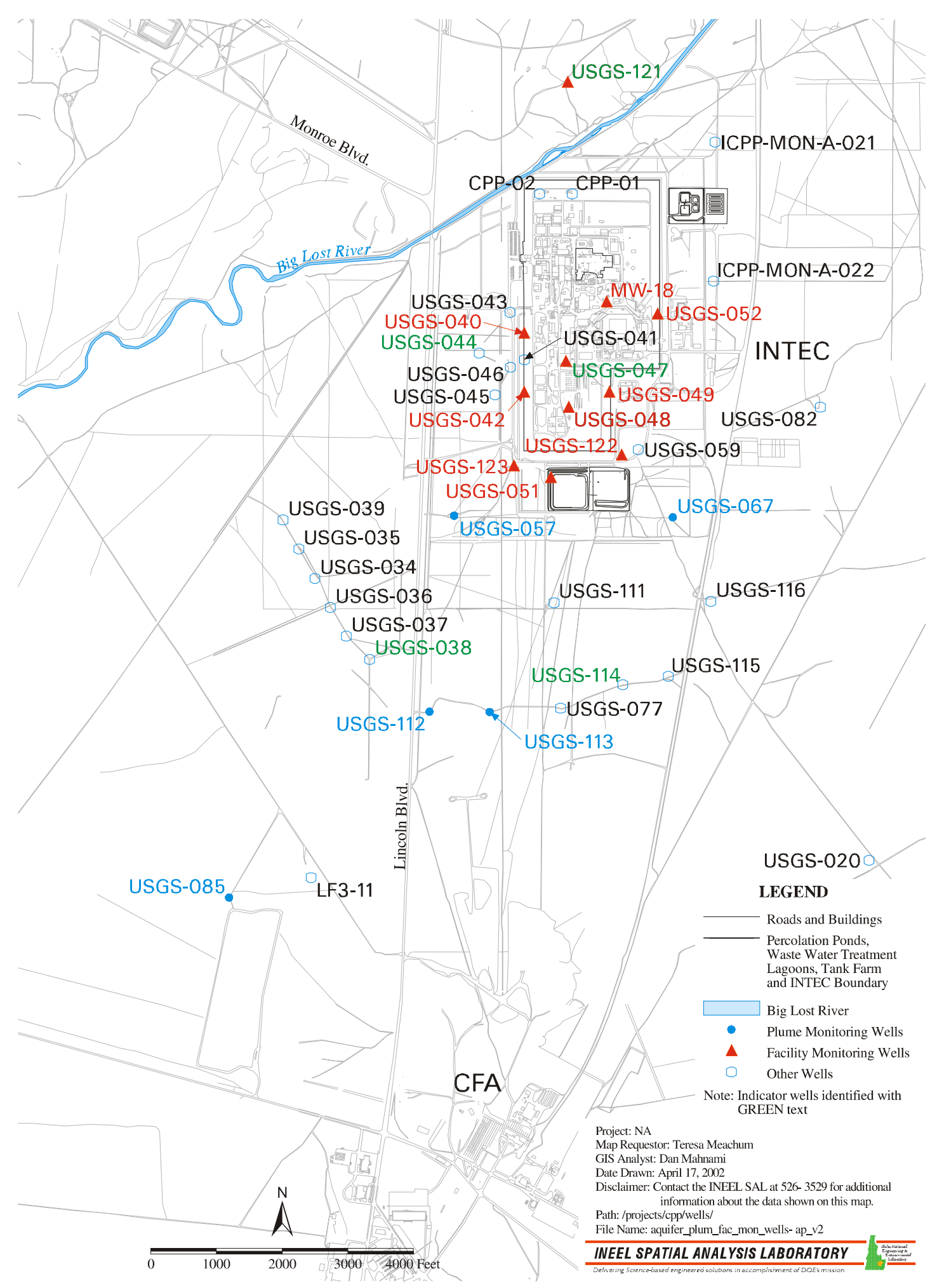

Figure 2. Locations of Idaho Nuclear Technology and Engineering Center monitoring wells. 
- $\quad$ USGS-047

- $\quad$ USGS-114

- $\quad$ USGS-121.

EPA Region IX has established, and EPA Region X has adopted, conservative, risk-based preliminary remediation goals (PRGs) for use in evaluating and cleaning up contaminated sites (EPA 1999b). The PRGs are chemical concentrations that correspond to the most stringent levels of risk; the PRGs correspond either to a one-in-one million (i.e., 1E-06) cancer risk or a noncarcinogenic hazard quotient of 1 , whichever is most stringent for the constituent.

DEQ has stated that the cumulative risk calculated from constituents in purge waters from the five INTEC indicator wells must be less than 1E-05 (based on PRG calculations) in order to determine if the purge water meets the conditional NLCI requirements. DEQ has also required annual monitoring of these wells to support the NLCI determination.

\section{INEEL GROUNDWATER MONITORING}

Groundwater monitoring is routinely performed across the INEEL in support of existing Wastewater Land Application Permits, Remedial Investigation/Feasibility Studies, and Records of Decisions for INEEL facilities. Groundwater Monitoring Program (GMP) personnel conduct the monitoring according to approved sampling and analysis plans and established technical procedures. In addition to collecting regular groundwater samples, field quality control samples are also prepared and collected. The following sections discuss the general sampling practices followed by GMP personnel and the quality assurance practices associated with the groundwater sampling. These practices were followed for the 2001 sampling of the five INTEC indicator wells.

\subsection{General Sampling Practices}

The Groundwater Monitoring Program has established technical procedures (TPRs) and management control procedures (MCPs) that are followed for all groundwater sampling. The procedures governing all groundwater sampling are listed in Table 1 and are provided in Appendix A.

These procedures address all aspects of groundwater sampling, including what preparation is required prior to going into the field to take the samples (TPR-6539), log-keeping (MCP-9227), general sample handling (TPR-6542), operation of sampling equipment (TPR-6573), taking groundwater level measurements (TPR-6566), taking groundwater and associated quality control samples (TPR-6570), equipment decontamination (TPR-6541, TPR-6574 and TPR-6575), and sample shipment and chain of custody (TPR-6542 and MCP-9228).

During calendar year 2001, groundwater sampling of the five indicator wells was performed in April and October 2001, with the October 2001 being the required annual sample for these wells. Applicable sample logbooks pages from both sampling events are included in Appendix B. For each well sampled, well purge data are entered into the logbook. 
Table 1. Procedures followed for groundwater sampling.

Procedure

Number $^{\mathrm{a}}$

Procedure Title

TPR-6539 Standardizing and Using the Hydrolab Datasonde for the Water Quality Multiprobe

TPR-6541 Decontaminating Sample Equipment

TPR-6542 Handling and Shipping Samples

TPR-6566 Measuring Groundwater Levels

TPR-6570 Sampling Groundwater

TPR-6573 Operating the Trailer-Mounted Pump Rig

TPR-6574 Decontaminating Heavy Equipment in the Field

TPR-6575 Decontaminating Sampling Equipment in the Field

MCP-9227 Environmental Monitoring Log-Keeping Practices

MCP-9228 Environmental Monitoring Sample Labeling and Chain of Custody

a. The referenced procedures are included, for information purposes only, in Appendix A of this report.

\subsection{Quality Assurance Practices}

The Groundwater Monitoring Program has quality assurance and quality control measures in place to ensure the effectiveness and reliability of the program. Several of the above referenced procedures provide a protocol for ensuring the accuracy of the groundwater sampling measurements. Correct standardization of the instrument used to take the field measurements ensures the accuracy of the field measurements. Correctly decontaminating sample equipment reduces the chance of cross-contamination of samples and ensures the accuracy of groundwater sample measurements. Proper handling of the samples, from sample preparation to sample shipment, ensures the permanent validity of the samples and compliance with applicable regulations and helps control damage or loss of samples. In addition to measures taken during regular sampling to ensure the quality of the groundwater sample measurements, the GMP has additional measures in place to assess the reliability and validity of field and laboratory measurements. These measures are discussed below.

\subsubsection{Field Quality Control Samples}

Section 4.9 of TPR-6570, "Sampling Groundwater," addresses field quality control (QC) samples to be taken by the GMP. The GMP relies on the sampling and analysis plans developed for each sampling event to specify the number and type of quality control samples to be taken. Specified within Section 4.9 of TPR-6570 are the guidelines on the use and handling of trip blanks, the preparation of field blanks, and the collection of equipment blanks and duplicates.

During 2001, the INTEC indicator wells were sampled in conjunction with sampling performed in support of the INEEL Wastewater Land Application Permits (WLAPs). The number of QC samples taken during these sampling events was based on the total number of samples required for the WLAPs and in support of the INTEC NLCI determination. The Sampling and Analysis Plans (SAPs) developed for both the April and October 2001 sampling are provided in Appendix C.

For each of the 2001 sampling events, GMP personnel collected duplicate samples at a rate of either one duplicate for every 20 samples collected or a minimum of $5 \%$ of the total number of samples 
for the sampling event. Duplicates were collected from the same location using the same technique and were placed in sample containers prepared in the same manner as the regular groundwater samples.

Field blanks are used to check the chemical preservation and environmental (ambient) contamination at the site. For the 2001 sampling events, the field blanks were collected at the same frequency as the field duplicates. The water used for the field blanks was obtained from the distilled/deionized water supply at INEEL facilities.

Equipment blanks were collected from the sample port manifold after decontamination and before use. Trip blanks were also collected and shipped with the volatile and semi-volatile samples.

\subsubsection{Analytical Laboratory Practices}

Analytical laboratories selected to perform the analysis of groundwater samples all have a Master Statement of Work (SOW) and a Task Order Statement of Work (TOS) in place prior to performing the analyses. The Master SOW and TOS list the parameters to be analyzed, the specific methods to be used, and the sample custody measures to follow that ensure the validity of the sample results. Required laboratory QC samples (i.e., matrix spikes, laboratory duplicates, and/or matrix spike duplicates) are specified in the methods used by the laboratory. Additional requirements, if any, are specified in the TOS. These steps ensure the accuracy and usability of the analytical results.

\subsubsection{Data Validation}

Analytical results obtained from the 2001 sampling of the indicator wells were validated to Level B as defined in the Guide Document (GDE)-7003, "Levels of Analytical Method Data Validation." Level B validation evaluates the following parameters associated with the sample and/or the analytical laboratory:

- Data completeness

- Gas chromatography/mass spectrometry (GC/MS) tuning

- Holding times/sample preservation

- Initial and continuing calibrations

- Blank analyses

- Surrogate recovery

- Matrix spike/matrix spike duplicate results

- Laboratory control sample results

- Internal standard recovery

- Tentatively identified compounds

- System performance and detection limits

Qualifier flags can be added to the reported analytical results as needed to address any data usability issues found during data validation. 


\section{2001 INTEC INDICATOR WELL MONITORING}

\subsection{Sampling Results}

The required annual sampling of the five indicator wells took place in October 2001. The five wells were also sampled in April 2001. The results of both 2001 sampling events are summarized in Tables 2 through 7 of this report. The April 2001 sample results were summarized and transmitted to DEQ in September 2001 (Rugg 2001b). The Limitations and Validation (L\&V) Reports (including the analytical laboratory reports) for the April 2001 sampling were provided to DEQ for information purposes on February 5, 2002. The analytical laboratory reports and associated L\&V Reports for the October 2001 sampling were provided to DEQ in April 2002. Also included in Tables 2 through 5 are the calculated risk for each detected constituent. A discussion of risk is presented in Section 4.3.

\subsubsection{Volatile and Semi-Volatile Organic Constituents}

Table 2 summarizes the detected organic results from the required annual sampling performed in October 2001. Only wells USGS-114 and USGS-047 had detected organic constituents reported from the October 2001 sampling; all organic constituents (both volatile and semi-volatile) for wells USGS-038, USGS-044, and USGS-121 were non-detects. For each constituent, Table 2 presents the analytical detection limit, associated Preliminary Remediation Goal (PRG), whether the PRG corresponds to a cancer risk (CA), 5 times the detection limit, the reported detected concentration, and the calculated risk, where applicable. Risk is calculated for each constituent if the concentration was detected and if the associated PRG is based on a cancer risk. Cumulative cancer risk for all organic constituents is also presented. Similar information is presented in Table 3 for the April 2001 sample event.

Two different laboratories performed the April 2001 and October 2001 organic analysis, resulting in different method detection limits (and $5 \mathrm{X}$ the detection limits) being shown in Tables 2 and 3. For most organic constituents, the method detection limit from the October 2001 analyses is lower than that used for the April 2001 organic analyses. Although some of the detection limits used for the October 2001 analysis are still above the associated PRG, the method detection limits are consistent with standard laboratory protocols for Appendix IX. Of those detection limits above the associated PRG, only three are above $1 \mu \mathrm{g} / \mathrm{L}$. These detection limits are for are 1,1-dichloroethene at $1.3 \mu \mathrm{g} / \mathrm{L}$, bis(2-chloroethyl)ether at $1.1 \mu \mathrm{g} / \mathrm{L}$, and dibenz(a,h)anthracene at $1.4 \mu \mathrm{g} / \mathrm{L}$.

Some analytical results were rejected during validation and are not considered usable. Poor surrogate recovery during the April semi-volatile analysis of the sample for USGS-047 resulted in the non-detected results being rejected, and October acetone non-detected results for USGS-047 were rejected during volatile organic validation due to initial and continuing calibration problems. As stated previously, the October sample represents the required annual sample. The rejected acetone result for USGS-047 from October had no impact on the cumulative risk for this well, since no cancer risk is calculated for acetone. No other 2001 organic results for the five indicator wells were rejected during validation.

\subsubsection{Tentatively Identified Compounds}

Tentatively identified compounds (TICs) reported by the analytical laboratories are summarized in Tables 4 and 5 for the October 2001 and April 2001 sample events, respectively. DEQ has requested an explanation of the unidentifiable compounds be provided with any summary of results (Monson 2001b). 


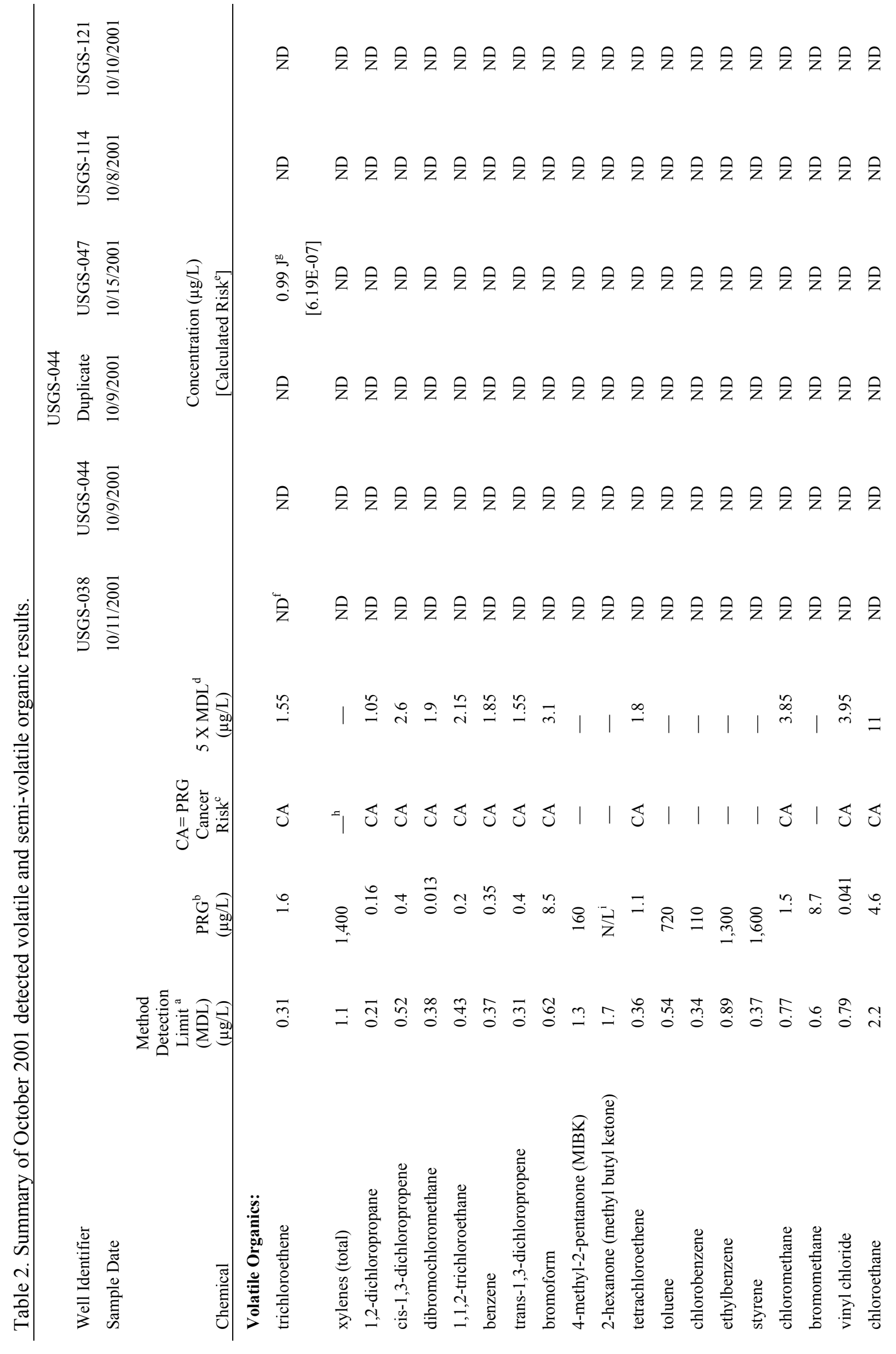




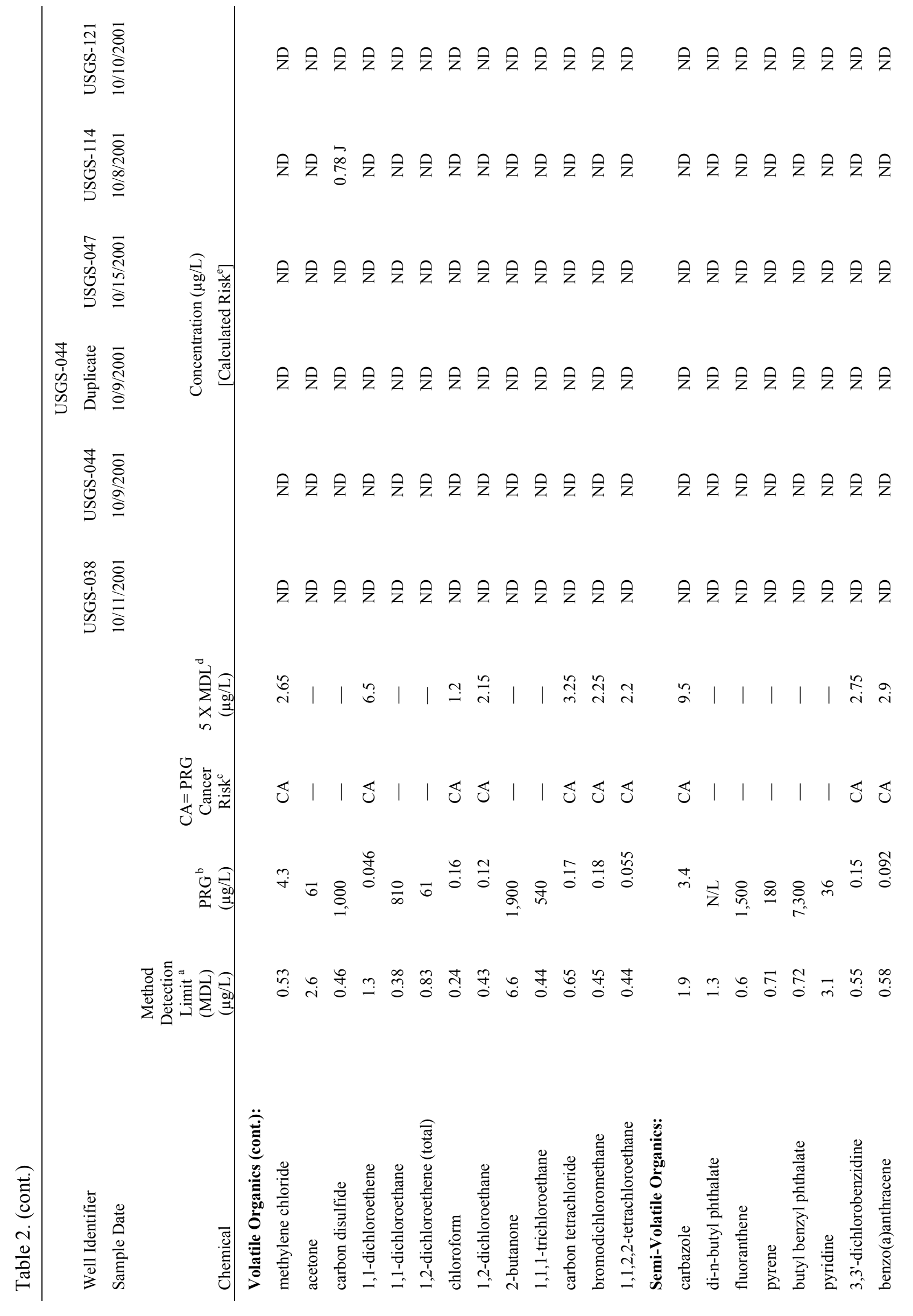




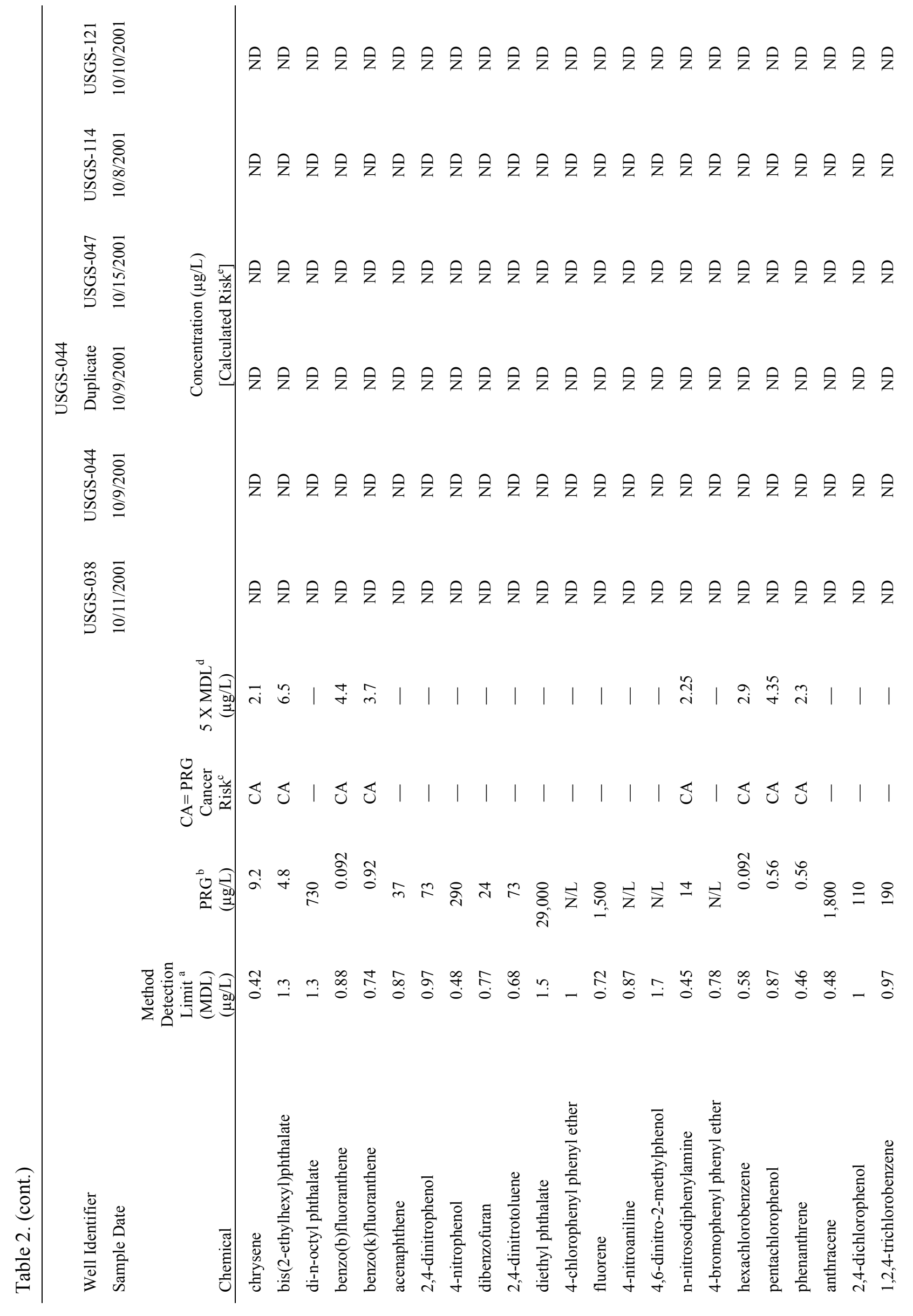




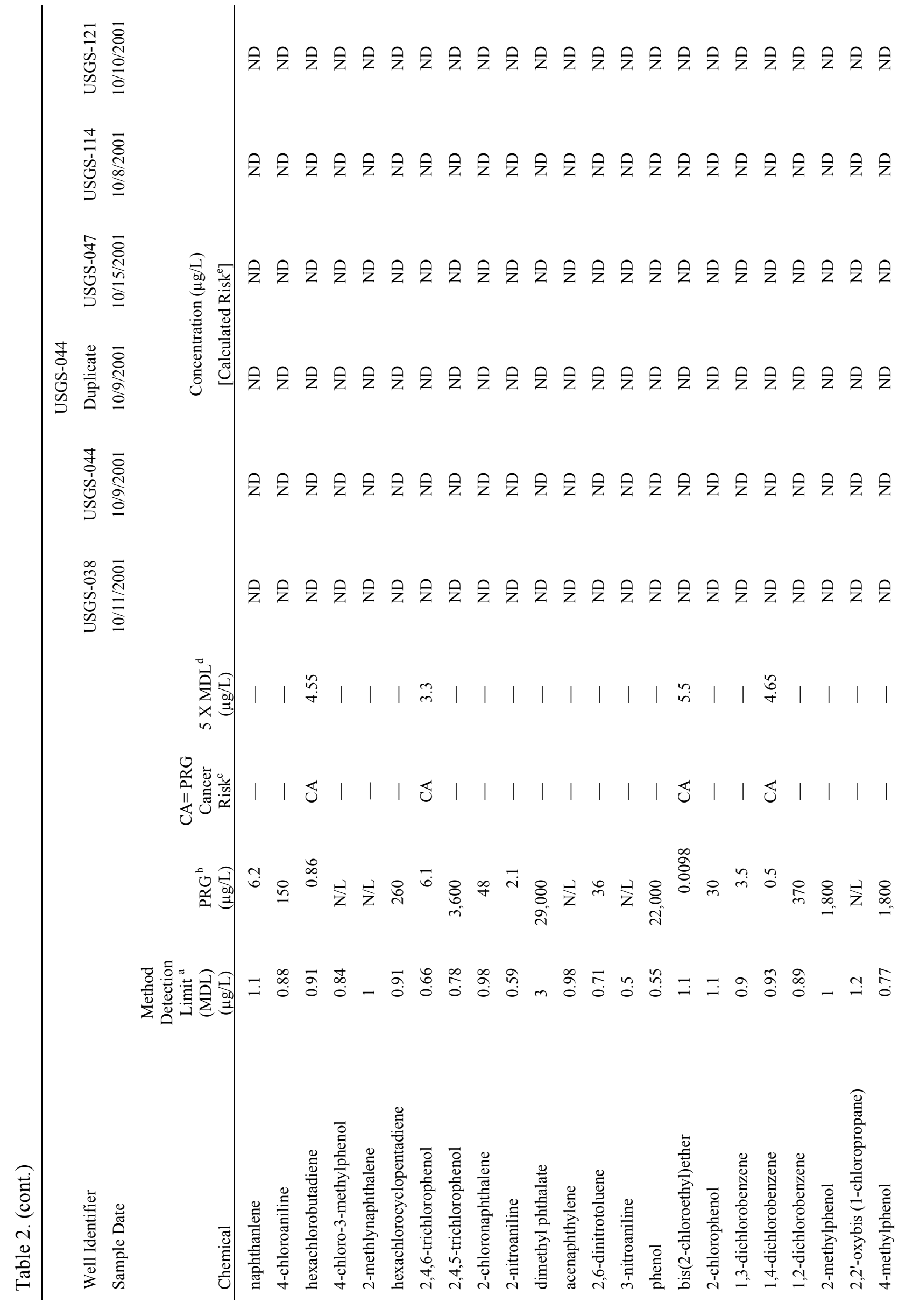




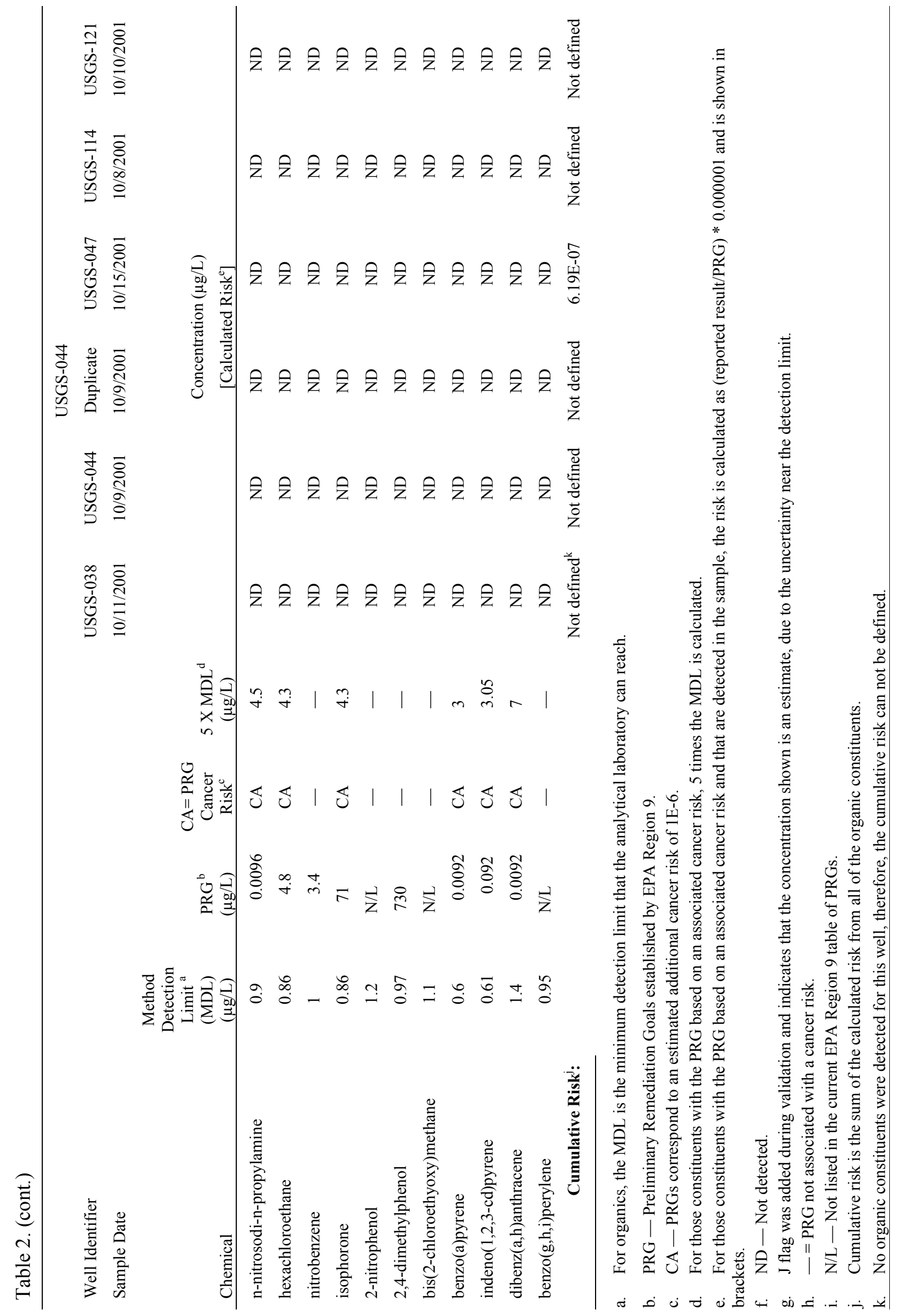




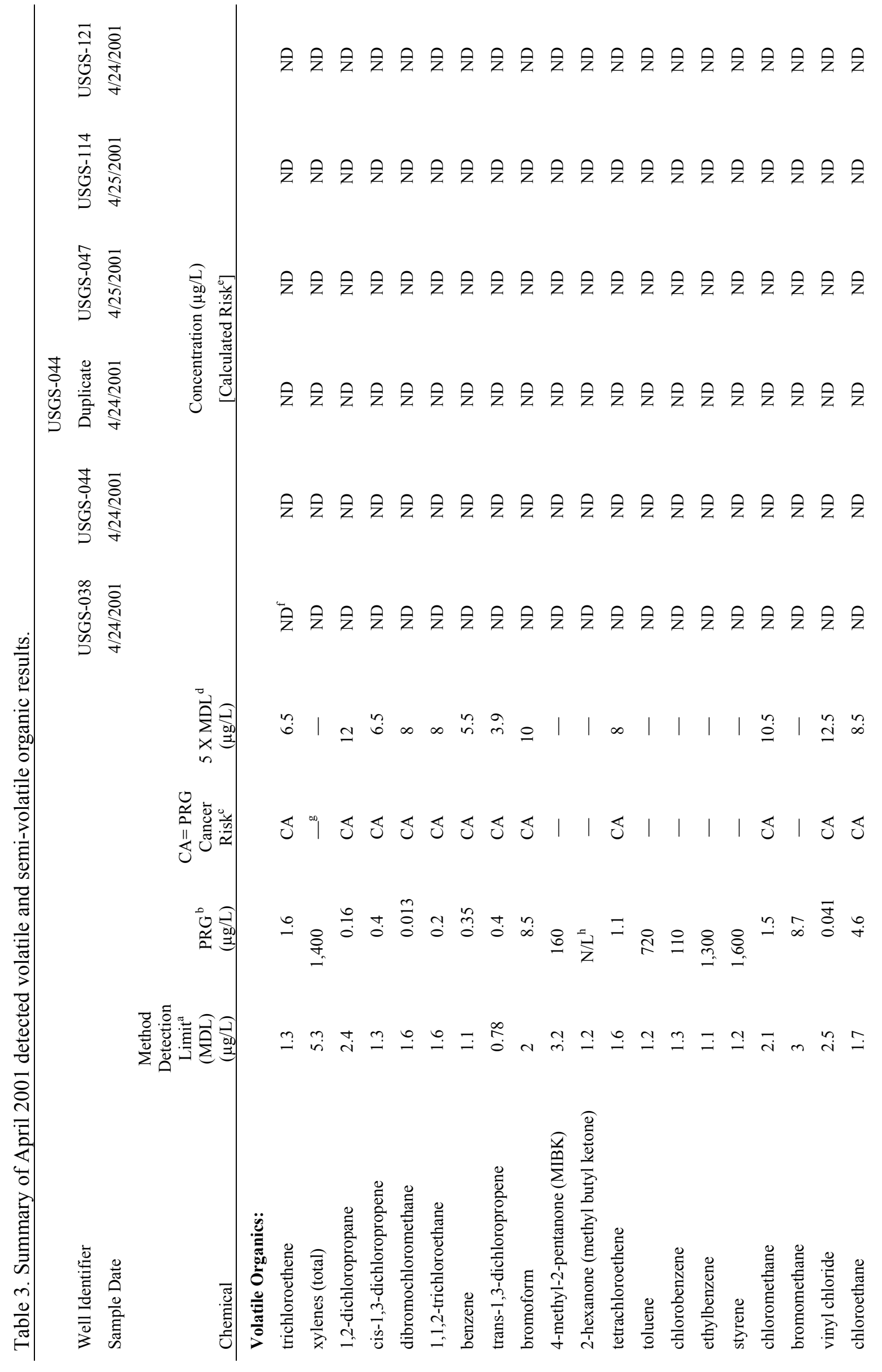




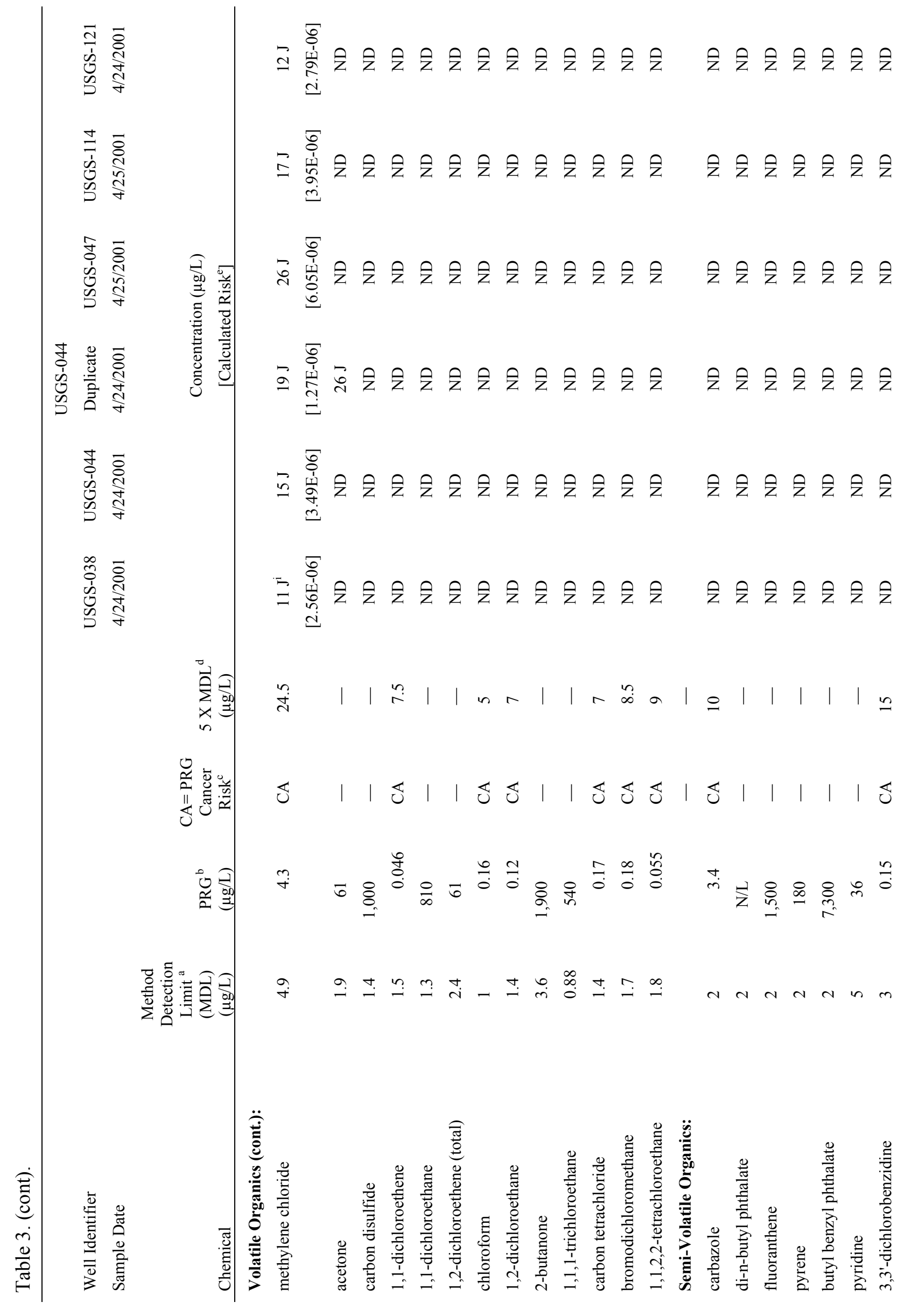




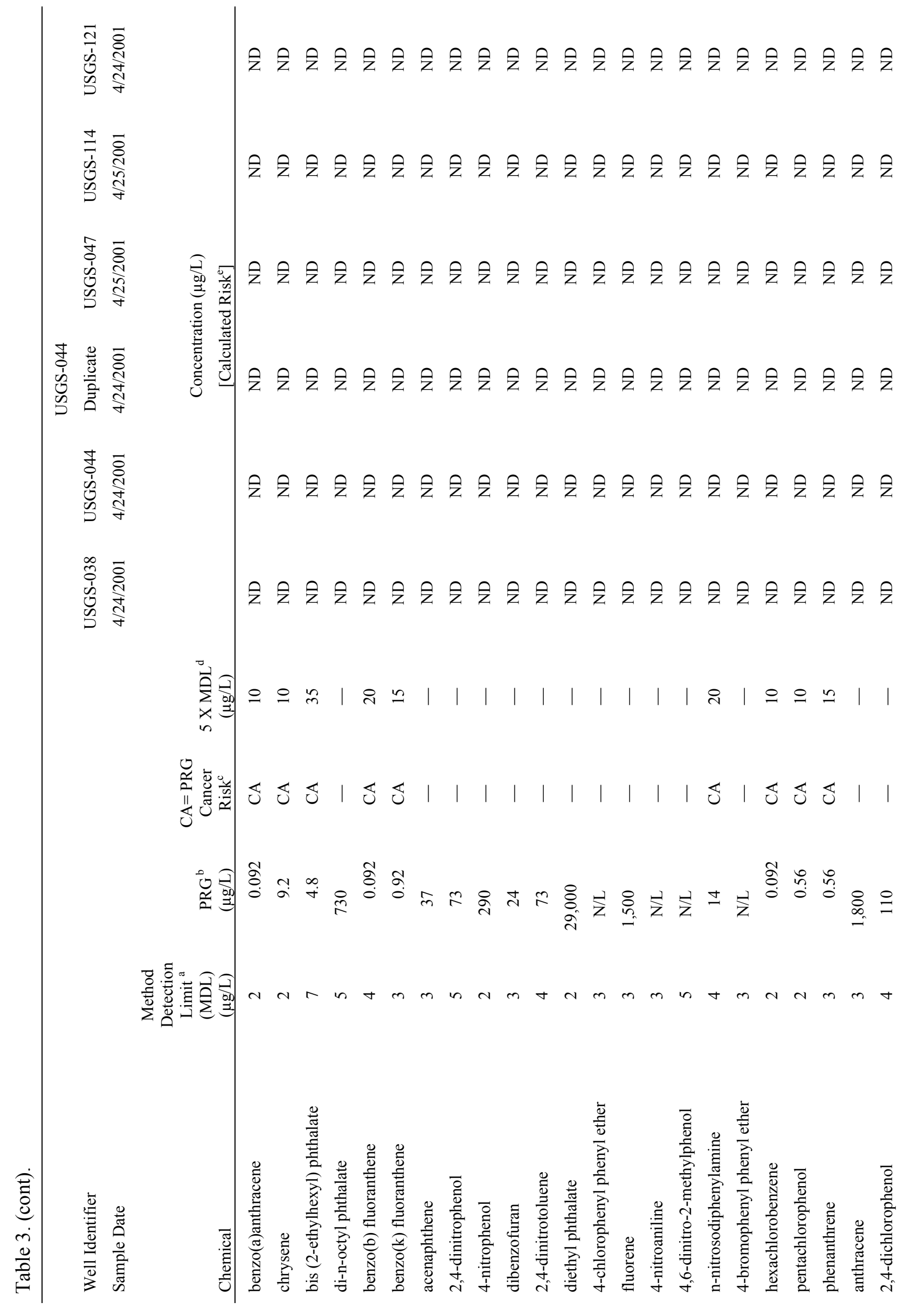




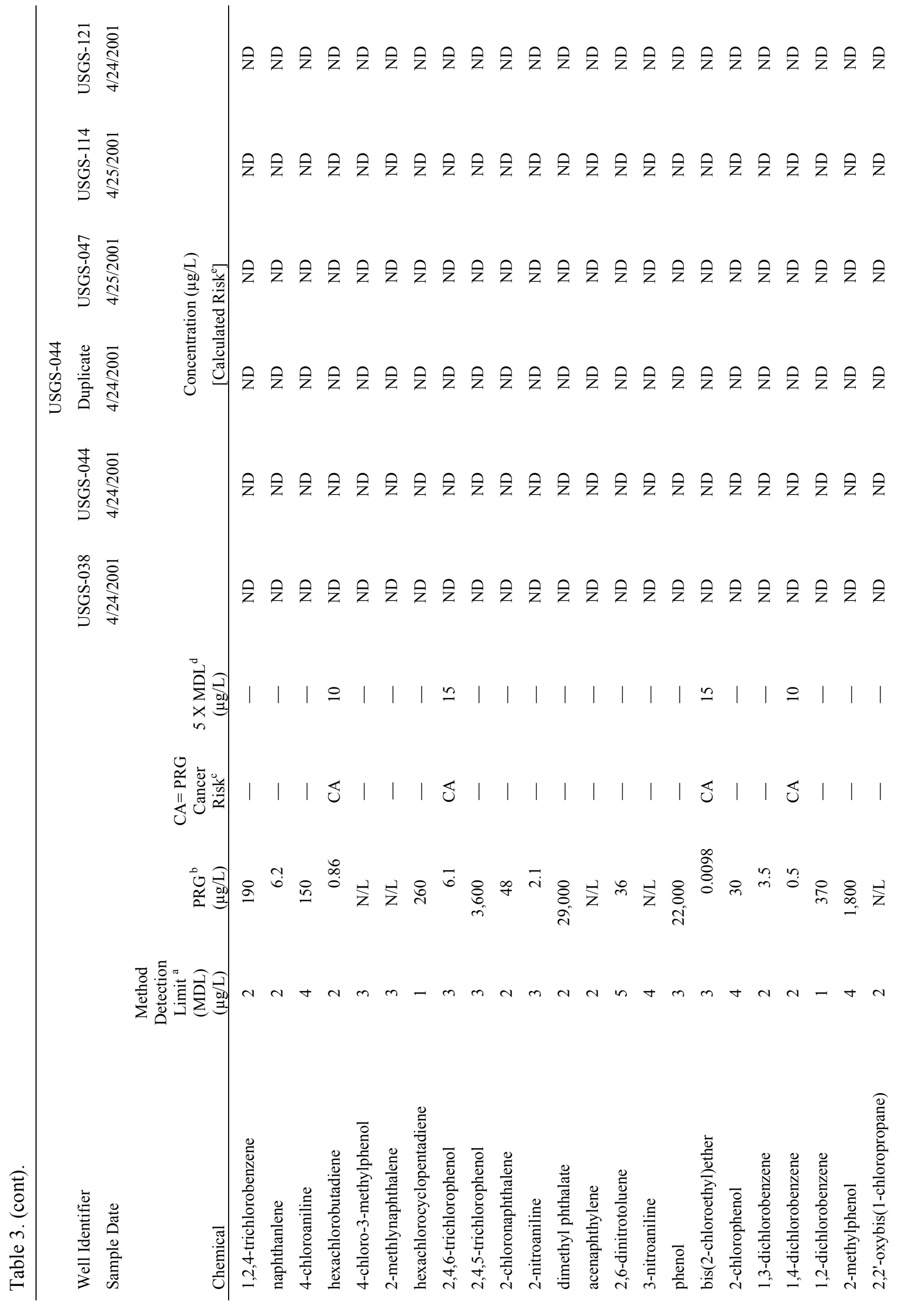




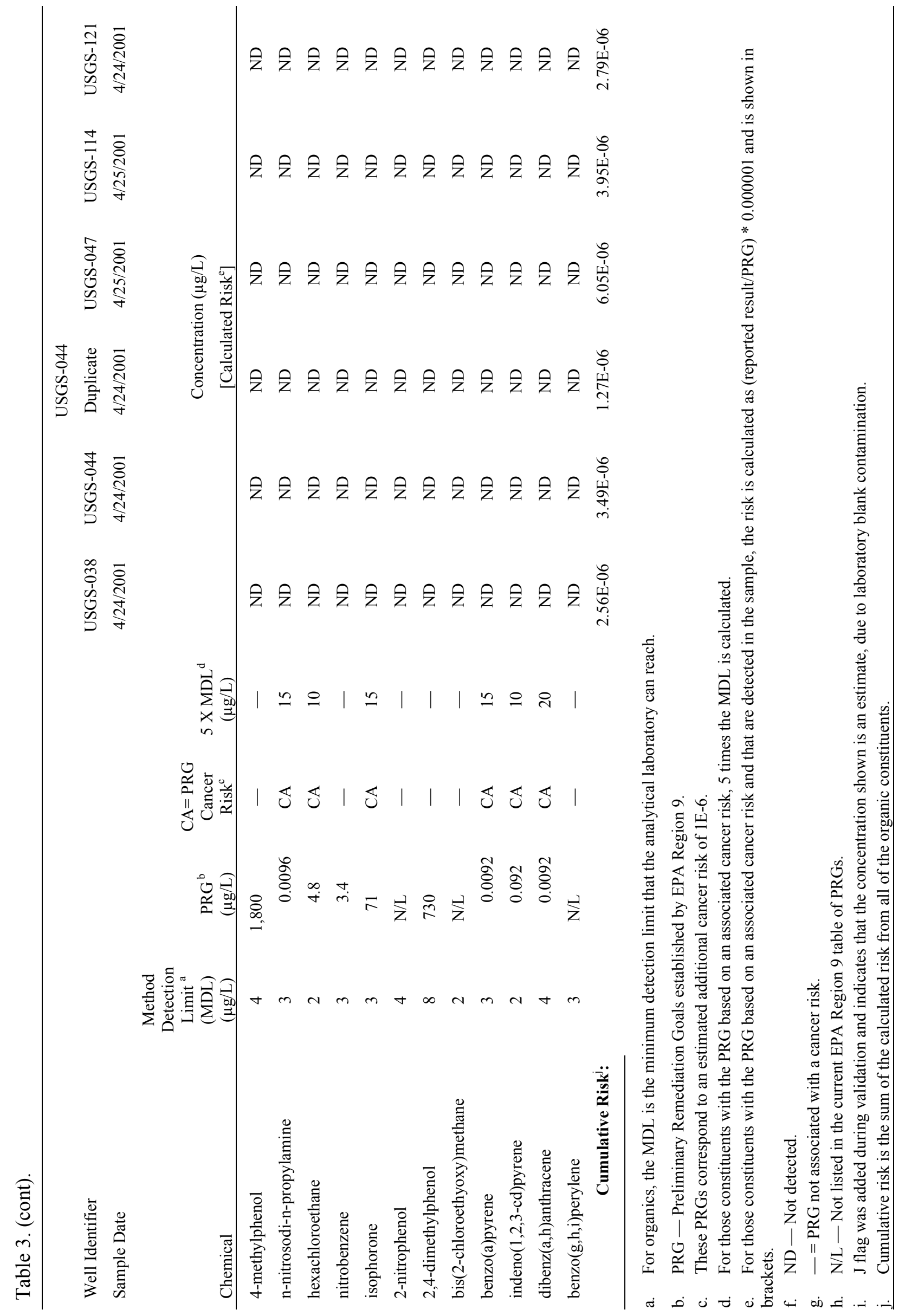




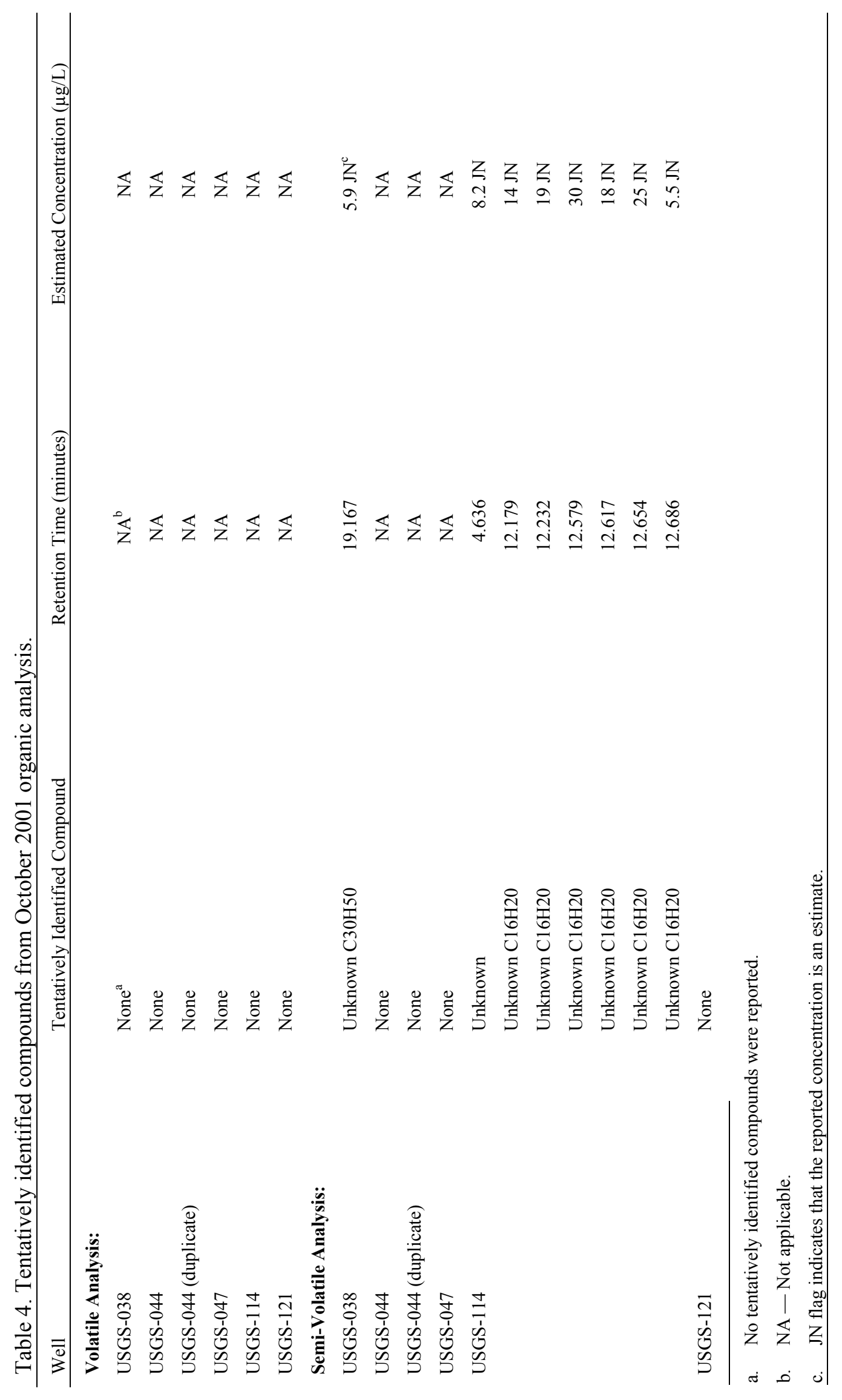




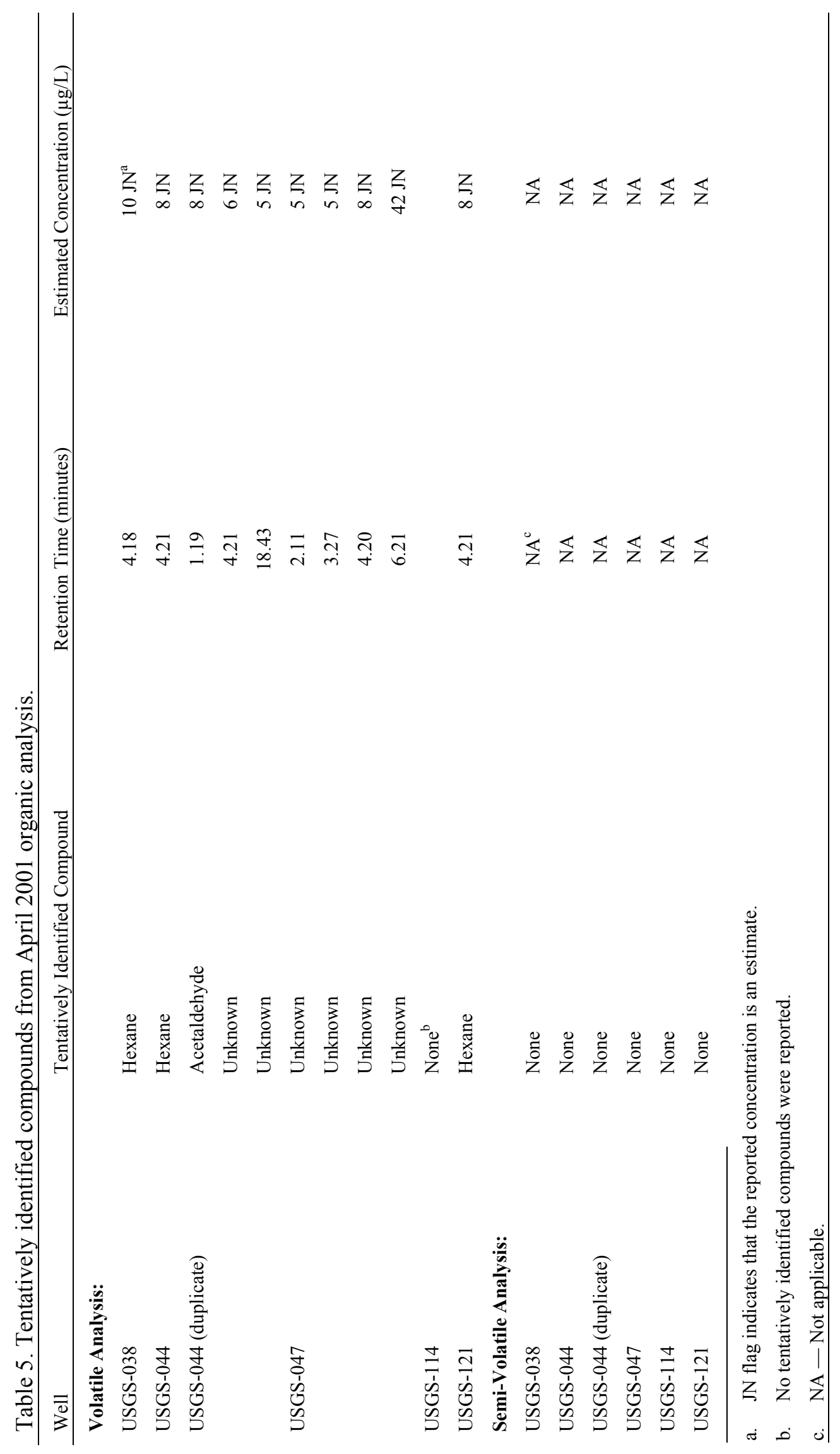




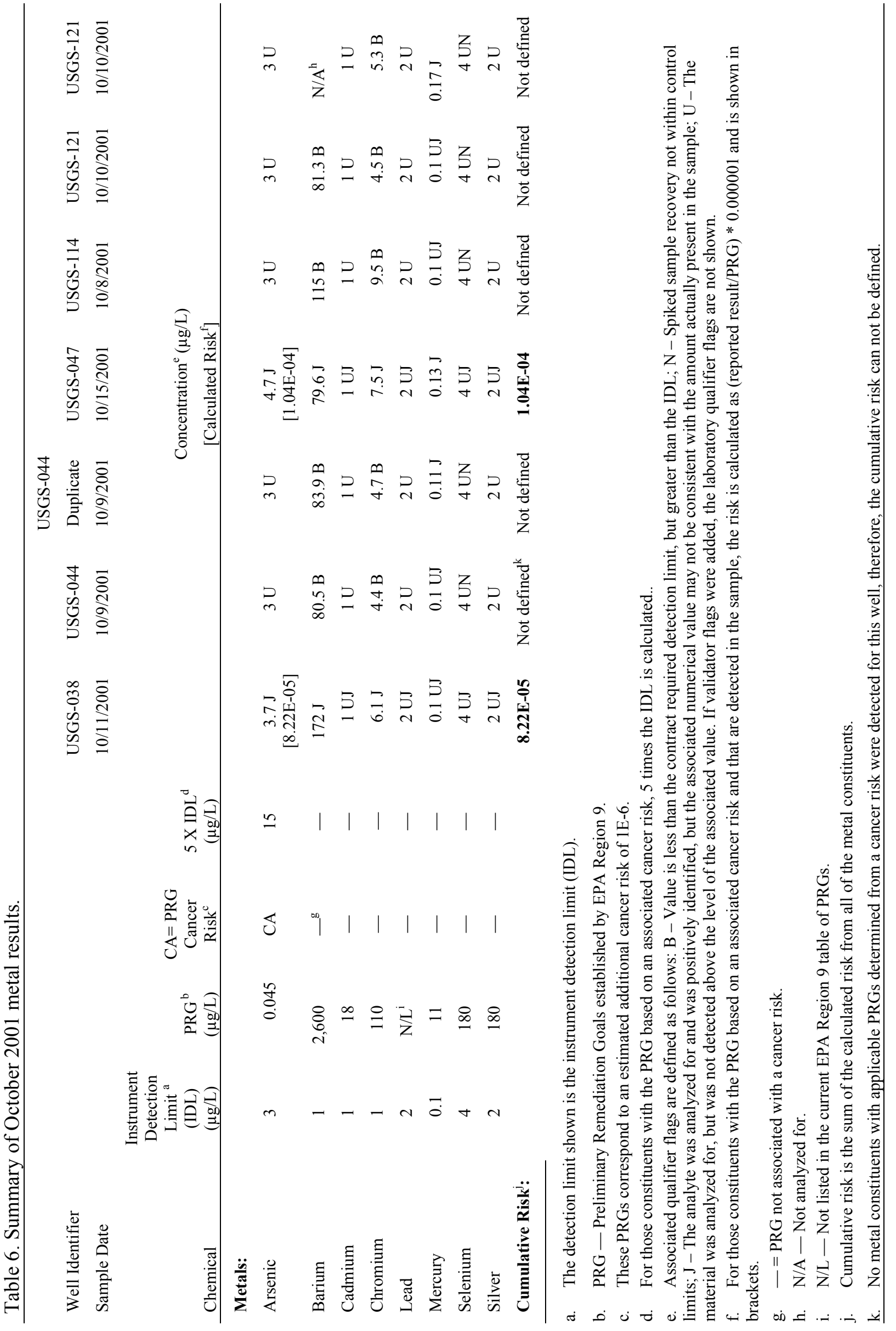




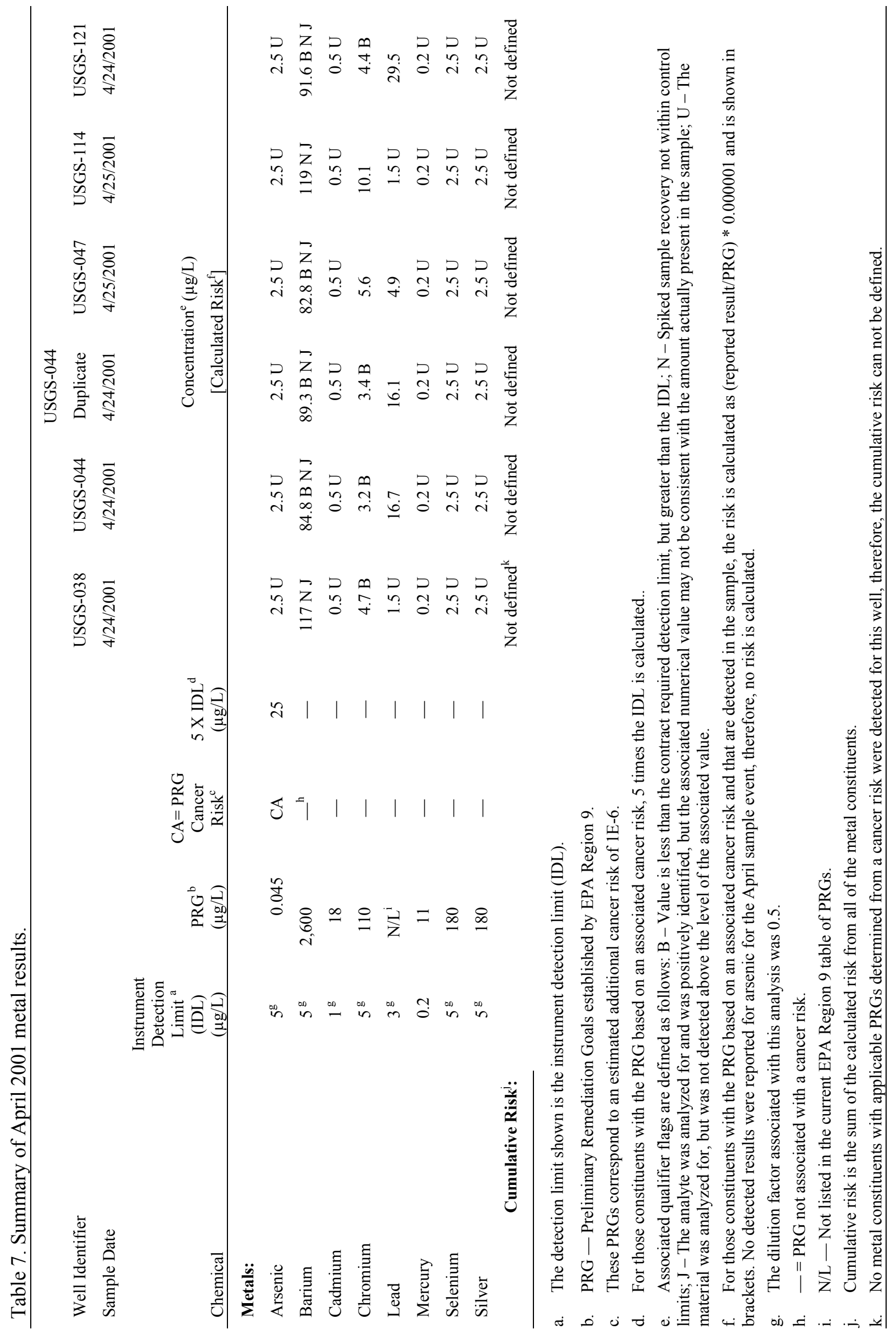


In addition to analyzing for target organic compounds in each gas chromatography/mass spectrometry (GC/MS) analysis, the organic Master SOW in place with an analytical laboratory directs the laboratory to perform mass spectral library searches to look for non-target analyte list compounds. The organic Master SOW follows the EPA Contract Laboratory Program guidance on identification of non-target organic compounds (EPA 1999a, Section 11). If the library search produces no matches at or above specified spectral match criteria, the laboratory is directed to report the compound as "unknown." If the library search produces a match with one or more compounds within specified criteria, the laboratory is directed to report a non-target compound name as a tentatively identified compound. The laboratory is directed to report TICs that have been assigned a tentative identification by a mass spectral interpretation specialist. Reported TIC concentrations are flagged (i.e., JN) indicating presumptive evidence of a compound at an estimated concentration.

For the October 2001 annual sampling for organic analyses, no tentatively identified volatile organic compounds were reported for any of the indicator wells. Several TICs were reported as unknown for USGS-114 from the October 2001 semi-volatile analysis. As stated above, the TICs are listed as unknown because the library search for non-target compounds did not find matches that met specified spectral match criteria requiring a tentative compound identification for the unknown peaks found during the semi-volatile analysis.

For the April 2001 organic analyses, no tentatively identified semi-volatile organic compounds were reported for any of the indicator wells. Volatile organic TICs were reported for four of the indicator wells, including the background well (USGS-121). The volatile organic TICs included hexane, acetaldehyde, and several unknown compounds. Hexane is considered a common laboratory contaminant. As stated above, the TICs listed as unknown, are unknown because the library search for the non-target compounds did not find matches that met specified criteria requiring a tentative compound identification for the unknown peaks found during the volatile analysis.

\subsubsection{Metal Constituents}

Table 6 summarizes the detected metal results from the required annual sampling performed in October 2001. For each constituent, Table 6 presents the analytical detection limit, associated PRG, whether the PRG corresponds to a cancer risk (CA), 5 times the detection limit, the reported detected concentration, and the calculated risk, where applicable. Risk is calculated for each constituent if the constituent was detected and if the associated PRG is based on a cancer risk. Cumulative cancer risk for metal constituents (arsenic) is also presented. Similar information is presented in Table 7 for the April 2001 sample event. Two different laboratories performed the April 2001 and October 2001 metals analysis, resulting in different instrument detection limits (and $5 \mathrm{X}$ the detection limits) being shown in Tables 6 and 7.

Arsenic is the only metal for which the PRG is based on a cancer risk. Therefore, the cumulative risk for metal constituents is determined solely from arsenic. For April 2001, all arsenic results are reported as non-detects. For October arsenic was detected in two of the wells (USGS-038 and USGS-047), therefore an associated risk is calculated.

For all metal constituents except mercury, the April 2001 samples were concentrated at the analytical laboratory prior to performing the analysis, resulting in a dilution factor of 0.5 . No dilution (or concentration) was performed by the analytical laboratory performing the October 2001 analysis.

No 2001 results from the metals analyses were rejected during validation for any of the five indicator wells. 


\subsection{Sampling Anomalies}

There were no sampling anomalies associated with the required annual sampling of the indicator wells, which took place in October 2001. During the April 2001 sampling event, a sample container collected for semi-volatile organic duplicate analyses from well USGS-44 arrived at the laboratory broken. The corrective action taken was to implement an intensive training program for all groundwater sampling personnel.

\subsection{Discussion of Cumulative Risk}

For each constituent, risk is calculated as follows:

$$
\left(\frac{\text { reported concentration }(\mu \mathrm{g} / \mathrm{L})}{\operatorname{associated~} \mathrm{PRG}(\mu \mathrm{g} / \mathrm{L})}\right) * 0.000001
$$

For each analysis type for each well, cumulative risk is the sum of the individual constituent risk for that well.

Based on the results of the October 2001 sampling of the five indicator wells, the cumulative risk associated with organic constituents is below the $1 \mathrm{E}-05$ cumulative risk required by DEQ for the NLCI determination.

For metal constituents, the cumulative risk (determined from arsenic) exceeds the 1E-05 cumulative risk set by DEQ for wells USGS-038 and USGS-047. Since arsenic was not detected in USGS-044, USGS-114, or USGS-121 in October, no risk was calculated. Arsenic was not detected in any of the five indicator wells in the April 2001 sampling.

\subsubsection{Arsenic}

The PRG for arsenic is $0.045 \mu \mathrm{g} / \mathrm{L}$ (based on a $1 \mathrm{E}-06$ cancer risk). In order to detect arsenic at levels equal to a $1 \mathrm{E}-05$ risk, the detection limit used should be below $0.45 \mu \mathrm{g} / \mathrm{L}$. However, neither analytical laboratory used for metals analysis during 2001 analyzed for arsenic at that low a level. The April arsenic instrument detection limit was $5 \mu \mathrm{g} / \mathrm{L}$. The October arsenic instrument detection limit was $3 \mu \mathrm{g} / \mathrm{L}$. While only two wells reported arsenic at detected levels (USGS-038 and USGS-047 in October), the associated risk from arsenic for the remaining samples can not be determined at the level needed to assess the required $1 \mathrm{E}-05$ risk.

While the risk associated with arsenic can not be determined at the levels required by DEQ, current concentrations of arsenic in the five indicator wells are within the ranges of past background levels in the SRPA. In general, background levels of arsenic in the SRPA are normally reported in the 2 to $3 \mu \mathrm{g} / \mathrm{L}$ range (Knobel, Orr, and Cecil 1992). However, sampling in 1989 detected concentrations of arsenic in the Magic Valley and Mud Lake areas that ranged from 1 to $5 \mu \mathrm{g} / \mathrm{L}$ (Knobel, Orr, and Cecil 1992), and previous sampling efforts detected concentrations of arsenic in 35 of 37 water samples collected from the SRPA that ranged from 1 to $21 \mu \mathrm{g} / \mathrm{L}$ (Wood and Low 1988). Additionally, arsenic was detected in the upgradient indicator well, USGS-121, in October 2000 at concentrations in excess of the PRGs (Rugg 2001a). Therefore, the concentration of, and associated risk from, arsenic detected in the five indicator wells are within background levels of arsenic detected in the SRPA and do not necessarily indicate an impact from INTEC operations. Arsenic levels detected in USGS-038 and USGS-047 in October 2001 were both below the recently adopted drinking water standard of $10 \mu \mathrm{g} / \mathrm{L}$. 


\subsection{Representativeness of 2001 Purge Water}

\subsubsection{To Other INTEC Monitoring Wells}

Four of the five indicator wells were selected as indicator wells for the other monitoring wells in the vicinity of INTEC either based on their location or historical concentrations of certain constituents. USGS-038, USGS-044, and USGS-114 were selected because historical concentrations from these wells show the maximum concentrations of certain constituents of interest. USGS-047 was selected because it is located downgradient from the former injection well. The fifth indicator well, USGS-121, was selected because it is upgradient of INTEC and is indicative of background of the SRPA (Rugg 2000).

DEQ agreed that sampling and analysis of these five wells would be sufficient for the determination of risk associated with volatile organics, semi-volatile organics, and metals present in purge waters collected in the vicinity of INTEC (Monson 2000).

To confirm the current representativeness of the five indicator wells to other INTEC monitoring wells, the results from the October sampling of the five indicator wells for metal constituents were compared to the results of the other INTEC aquifer wells sampled at the same time in support of the WLAPs for INTEC. Other aquifer wells in the vicinity of INTEC sampled in October 2001 as part of the same sampling event include USGS-048, USGS-052, USGS-112, and USGS-113. Table 8 presents a comparison of the range of concentrations, for the metal constituents, from the five indicator wells and the other INTEC aquifer wells sampled at the same time in October 2001. The other INTEC aquifer wells sampled in October 2001 in support of the WLAPs were not sampled for organics, therefore, no comparison is provided.

Based on October 2001 sampling results, the 2001 concentrations of the metal constituents indicate that the five indicator wells can still be considered as representative of other INTEC monitoring wells.

Table 8. Constituent concentration ranges from indicator wells and other INTEC wells sampled in October 2001 for metal constituents.

\begin{tabular}{lcc}
\hline Constituent & $\begin{array}{c}\text { Indicator Well Range } \\
(\mu \mathrm{g} / \mathrm{L})\end{array}$ & $\begin{array}{c}\text { Other INTEC Well Range }{ }^{\mathrm{a}, \mathrm{b}} \\
(\mu \mathrm{g} / \mathrm{L})\end{array}$ \\
\hline $\begin{array}{l}\text { Arsenic } \\
\text { Barium }\end{array}$ & $\begin{array}{c}\mathrm{U}^{\mathrm{c}}-4.7 \mathrm{~J}^{\mathrm{c}} \\
79.6 \mathrm{~J}-115\end{array}$ & $3 \mathrm{U}$ \\
Cadmium & $1 \mathrm{U}$ & $\mathrm{N} / \mathrm{A}^{\mathrm{d}}$ \\
Chromium & $4.4-9.5$ & $1 \mathrm{U}$ \\
Lead & $2 \mathrm{U}$ & $5.9-6.8$ \\
Mercury & $0.1 \mathrm{U}-0.17 \mathrm{~J}$ & $2 \mathrm{U}$ \\
Selenium & $4 \mathrm{U}$ & $0.1 \mathrm{U}-0.22 \mathrm{~J}$ \\
Silver & $2 \mathrm{U}$ & $3 \mathrm{U}-4 \mathrm{U}$ \\
\hline a. $\quad$ Only one value is shown for the range if the same result was reported for all wells. & $1 \mathrm{U}-2 \mathrm{U}$ \\
b. Other INTEC wells considered for these ranges include USGS-048, USGS-052, USGS-112, and USGS-113. \\
c. U flag indicates the reported result was considered a non-detect; J flag indicates the reported result was an estimate. \\
d. N/A - constituent was not analyzed for these wells.
\end{tabular}




\subsubsection{To Saturated Zones}

Table 9 presents the well depths for the five indicator wells and the prepurge water levels from the October 2001 sampling. The five indicator wells were all sampled during October 2001 at depths representative of the SRPA in the vicinity of INTEC.

Table 9. 2001 well depths and prepurge water levels for five INTEC indicator wells.

\begin{tabular}{lcc}
\hline Well & $\begin{array}{c}\text { Well Completion Depth } \\
\text { (feet) }\end{array}$ & $\begin{array}{c}\text { October 2001 Prepurge Water Level } \\
\text { (feet) }\end{array}$ \\
\hline USGS-038 & 729 & 473.9 \\
USGS-044 & 650 & 463.61 \\
USGS-047 & 651.3 & 458.77 \\
USGS-114 & 560 & 472.3 \\
USGS-121 & 475 & 453.74 \\
\hline
\end{tabular}

\subsection{Continued Annual Monitoring}

The five indicator wells will continue to be sampled on annually as required by DEQ (Monson 2000). The annual sampling will continue to be performed in October of each year. As additional sampling occurs and sufficient data are collected, trends will be assessed and documented. 


\section{REFERENCES}

DOE-ID, 1999, Comprehensive Environmental Response, Compensation and Liability Act (CERCLA) Record of Decision (ROD) for Operating Unit OU 3-13 at the Idaho National Engineering and Environmental Laboratory (INEEL), DOE/ID-10514, September 1999.

EPA, 1999a, USEPA Contract Laboratory Program Statement of Work for Organics Analysis, Multi-Media, Multi-Concentration, OLM04.2, May 1999.

EPA, 1999b, Region 9 Preliminary Remediation Goals (PRGs), http://www.epa.gov/region09/waste/sfund/prg/s3_01.htm, October 1, 1999.

GDE-7003, 2001, Levels of Analytical Method Data Validation, March 2001.

Graham, J. F., INEEL, to G. Eager, DEQ, January 3, 2000a, "Wastewater Land Application Permit Application for the Idaho Nuclear Technology and Engineering Center New Percolation Ponds," CCN 00-001573.

Guymon, R. H., INEEL, to B. R. Monson, DEQ, February 1, 2000, "Request for a No Longer Contained In Determination for Environmental Media and Debris Downgradient of Idaho Nuclear Technology and Engineering Center," CCN 00-004143.

Hall, V., DEQ, to C. M. Bennett, DOE-ID, May 18, 2000, "Idaho Nuclear Technology and Engineering Center (INTEC) Service Wastewater Discharge Facility, New Percolation Ponds, Idaho National Engineering and Environmental Laboratory," TSCE-32-2000.

INEEL, 2000, Request for No Longer Contained-In Determination Covering Environmental Media and/or Debris Generated from Activities Involving the Snake River Plain Aquifer Within and Downgradient of the Idaho Nuclear Engineering and Technology Center, INEEL/EXT-200000041, January 2001.

Knobel, L. L., B. R. Orr, and L. D. Cecil, 1992, "Summary of Background Concentrations of Selected Radiochemical and Chemical Constituents in Groundwater from the Snake River Plain Aquifer, Idaho: Estimated from an Analysis of Previously Published Data," Journal of the Idaho Academy of Science, Vol. 28, No. 1, pp. 48-61, June 1992.

Lewis, B. D. and R. G. Jensen (USGS), 1984, Hydrologic Condition at the Idaho National Engineering Laboratory, Idaho: 1979-1981 Update, Open-file Report 84-230.

Monson, B. R., DEQ, to D. Wessman, DOE-ID, August 21, 2000, "Conditional No Longer Contained In Determination (NLCID) for the Snake River Plain Aquifer (SRPA) in the Vicinity of the INEEL INTEC Facility (EPA ID No. ID4890008952)"

Monson, B. R., DEQ, to D. Wessman, DOE-ID, April 26, 2001a, "Conditional No Longer Contained In Determination (NLCID) for the Snake River Plain Aquifer (SRPA) in the Vicinity of the INEEL INTEC Facility (EPA ID No. ID4890008952)"

Monson, B. R., DEQ, to D. Wessman, DOE-ID, December 21, 2001b, "Results of the Conditional No Longer Contained in Determination Sampling, Received October 1, 2001, at the Idaho Nuclear 
Technology and Engineering Center, Idaho National Engineering and Environmental Laboratory, EPA ID No. ID4890008952."

Robertson, J. B. (USGS), 1974, Digital Modeling of Radioactive and Chemical Water Transport in the Snake River Plain Aquifer at the National Reactor Testing Station, Idaho, Open-File Report, IDO-22054.

Rugg, J. E., INEEL, to R. E. Bullock, DEQ, June 8, 2000, "Snake River Plain Aquifer Listed Waste Issue," CCN 00-009535.

Rugg, J. E., INEEL, to R. E. Bullock, DEQ, February 19, 2001a, "Conditional No Longer Contained-In Determination For the Snake River Plain Aquifer in the Vicinity of the Idaho National Engineering and Environmental Laboratory (INEEL) Idaho Nuclear Technology and Engineering Center (INTEC) Facility (EPA ID NO. ID4890008952)," CCN 017869.

Rugg, J. E., INEEL, to B. R. Monson, DEQ, September 27, 2001b, "Regarding Conditional No Longer Contained-In Determination (NLCID) for the Snake River Plain Aquifer in the Vicinity of the Idaho Nuclear Technology and Engineering Center (INTEC)," CCN 26171.

Wood, W. W., and W. H. Low, 1988, Solute Geochemistry of the Snake River Plain Regional Aquifer System, Idaho and eastern Oregon, USGS Geological Survey Professional Paper 1408-D. 79p. 


\section{Appendix A \\ Environmental Monitoring Technical Procedures}




$$
\text { A-2 }
$$


Appendix B

Sample Logbook Pages

B-1 
B-2 


\section{April 2001 Sample Logbook Pages}


B-4 


\section{October 2001 Sample Logbook Pages}


B-26 


\section{Appendix C \\ Sample and Analysis Plans}


C-2 